'Specialist' Schemes"; Miss Barbara R. F. Kyle's "Lessons Learned from Experience in Drafting the Kyle Classification"; J. Mills's "Inadequacies of Existing General Classification Schemes"; and E. J. Coates's "The Classification Research Groups Proposals for a New General Classification". In a final statement resulting from the discussions, the conference agreed that the primary purpose of the new classification should be for the manual retrieval of books on shelves and entries in indexes. The theory of integration levels, supplemented by other principles, would provide a starting point for the main basic order. It would be necessary to work out a system of eategorization of terms and at least a minimum set of relations, while complex terms would need analysis or dissection up to a point to be determined. The final systom chosen should have international acceptance.

\section{Parasitic Infection and Tumoral Growth}

IN mice inoculated with ascites tumour (sarcoma $M C l M$ ) and simultaneously infected with Toxoplasma Gondii, Dr. Tulio Pizzi and Dr. Maria Diaz, of the School of Medicine, University of Chile, have shown that tumour cells were invaded by the parasite in about the same proportion as the non-tumoral host cells (Biologica, Faculty of Medicine, University of Chile, 34; July 1963). The neoplastic celis were apparently not damaged by the parasite and their mitotic index was similar to that found in the non-infected controls. A sharp fall in the number of tumour cells in animals infected with Toxoplasma was observed on the fourth day when animals were agonic. This action is probably explained by non-specific factors.

\section{The Institution of Metallurgists}

At the twontieth annual general meeting of the Institution of Metallurgists, held on May 13 at the Park Lane Hotel, London, Dr. L. Rotherham, member for research, Central Electricity Gonerating Board, was elected president for the year 196465 , in succession to Dr. L. Northcott. The following elections were also made: Vice-Presidents, Mr. N. I. Bond-Williams (director, Enfield Rolling Mills) and Mr. H. Morrogh (director of the British Cast Iron Research Association); Honorary Treasurer, Mr. L. W. Derry (head of the Metallurgy Department, Battersea College of Advanced Technology); Ordinary Members of Council elected by the Fellows, Mr. L. Grainger (chief technical and development officer, Richard Thomas and Baldwins, Ltd.) and Mr. R. Wileock (chief metallurgist, Samuel Fox and Co., Ltd.); Ordinary Member of Council elected by the Associates, Mr. P. C. Thornton (principal lecturer in metallurgy, Bristol College of Science and Technology).

\section{Beit Memorial Fellowships for Medical Research}

THE following elections to Beit Memorial fellowships for medical research have been announced: Junior Fellowships, J. G. Edwards, to investigate the molecular basis of enzyme induction and the structure and function of messenger RNA in Pseudomonas aeruginosa, at the Department of Biochemistry, University College, London; D. M. Gill, to investigate protein synthesis, especially of histones, in isolated nuclei and nucleoli, at the Department of Radiotherapeutics, Cambridge; Michael Hallinan, to investigate the effect of the vitamins $A$ and $\mathrm{E}$ on the structure of rough and smooth-surfaced endoplasmic reticulum in mammalian cells, at the Strangeways Research Laboratory, Cambridge; J. G. Hall, to investigate the initiation and propagation of immunity in the lymphatic system in the unanæsthetized sheep, at the Institute of Animal Physiology, Babraham, Cambridge; B. L. Ardill, to investigate pattern variations of intrinsic vascular response of the peripheral circulation occasioned by changes in the physical properties of the blood, at the Department of Physiology, St. Mary's Hospital Medical School, London; D. L. Doxey, to investigate the response of animal lymphocytes to challenge by Johne's disease antigens in vitro, at the Department of Veterinary Clinical Science, Cambridge. Senior Fellowship, Dr. E. R. Huehns, to investigate the proteins of red blood cells in thalassæmia, hæmoglobinopathies and other red cell abnormalities, at the Medical Unit, University Collego Hospital Medical School, London.

Dame Honor Fell was reappointed a member of the Advisory Board for another five years, and Prof. W. G. Spector (St. Bartholomew's Hospital Medical College, London) was appointed secretary to the Trust on the retirement of Sir Roy Cameron. The secretary's fiveyearly report was adopted.

\section{Announcements}

The Meldola Medal for 1963 has been awarded to Dr. Alan Carrington, assistant director of research in the Department of Theoretical Chemistry, University of Cambridge, for his work in the field of physical and theoretical chemistry, with special reference to the measurement and interpretation of electron spin resonance spectra. The award is made by the Council of the Royal Institute of Chemistry, with the concurrence of the Society of Maccabaeans.

A symposium on "The Teaching of Materials Science" will be held at Sunderland Technical College during July 2-3. Further information can be obtained from the Registrar, Technical College, Sunderland, County Durham.

A symposrum on "Pollution", arranged by the Western Section of the Society for Analytical Chemistry, will be held in the University of Swansea during July 2-4. Further information can be obtained from Dr. T. G. Morris, Brockleigh, Clevedon Avenue, Sully, Glamorgan.

A ONE-WEEK summer session on "Thermodynamics, a Unifying Science" will be held at the Massachusetts Institute of Technology during June 29-July 3 . It is intended for engineers and scientists interested in research, development and teaching. Further information can be obtained from the Summer Session Office, Massachusetts Institute of Technology, Cambridge, Mass.

A symposium on "Signal Processing in Radar and Sonar Directional Systems", sponsored jointly by the British Institution of Radio Engineers and the Department of Electrical Engineering of the University of Birmingham, will be held in the University of Birming. ham during July 6-9. Further information can be obtained from tho British Institution of Radio Engineors, 9 Bedford Square, London, W.C.1.

The Torry Research Station, Aberdeen, will hold open days during July 1-2. The exhibition of work in progress will include displays on all aspects of fish preservation, quality, spoilage, freezing and cold storage, thawing, smoking and drying, analysis, biochemical research on composition, structure, flavour and texture of fish flesh. Further information can be obtained from the Director, Torry Research Station, Abbey Road, Aberdeen.

Three international conferences dealing with rust diseases of cereal crops will be held in Cambridge during June 29-July 4. The conferences will be: third European yellow rust conference (June 29-30); first international brown rust conference (July 1); third European coloquium on black rust of cereals (July 2-3). Further information can be obtained from R. J. F. Macer, Plant Breeding Institute, Maris Lane, Trumpington, Cambridge.

THE fifth annual summer school in "Health Physics (Radiation Protection)", arranged by Dr. H. D. Evans, will be held at the Imperial College of Science and Technology during June 29-July 10. The course is designed primarily for graduates in science, engineering or medicine whose work involves the use of radiation or radioactive materials, or whose duties involve radiation protection. Further information can be obtained from the Registrar, Imperial College, London, S.W.7. The fee for the course is 25 guineas. 